\title{
GOAT BREEDING, NEED AND POSSIBILITY IN HOUSEHOLDS LOCATED IN HILLY-MOUNTAINOUS AND PLAIN REGIONS ${ }^{1}$
}

\author{
M. Žujović, Zorica Tomić, M.P. Petrović, Snežana Ivanović, Zorica Nešić2
}

Content: Goat breeding as one of the branches of livestock production today is currently at the lowest production and economical level for the last forty years, therefore it is necessary to understand and point out the importance of goat breeding for overall economical development of our country, improvement of the standard of living, better employment rate of rural population which makes approx. 25 to $30 \%$ of total population directly or indirectly connected to rural regions. It is necessary to define long term programme for development of goat production which would be realized and enforced obligatory and in full responsibility. As consequence of absence of engagement in relation to this field of livestock production will be further lacking behind developed world.

Objective of this paper was to present general review of conditions, current situation and problems existing in goat production and suggest and recommend solutions for this production for next ten years. Special emphasis is on individual farms/agricultural households in hilly-mountainous and plain regions which would engage in this production as their primary production activity.

Key words: goat, farm, breeding, production.

\section{Introduction}

Number of goats in relation to existing agricultural surface is unsatisfactory and represents important resource for economy of our country in general. Therefore, intensifying of goat production and increase of its share in livestock production is main demand and need in order to overcome further lagging behind other countries and avoid uncertainties and hesitations in regard to providing of food for population and stop unnecessary and unorganized import of meat, milk and breeding material which is very harmful and damaging to overall agricultural potentials. Developed industrial countries have developed livestock production, including goat breeding.

It is necessary to realize that there is no developed economy with agriculture - and especially livestock production - in stagnation or decrease in regard to number of heads of livestock as well as quality of production. Therefore, long term defined programme of development of livestock production would contribute to overcoming of such problems and would direct agriculture towards intensifying of goat production.

According to our knowledge, developed and stable goat production as well as livestock production in general in our country depend on:

- Natural resources,

- Market,

- Long term objectives of livestock - goat production,

- Quality and quantity of goats and their products.

\section{Factors determining present condition in goat breeding}

Our country disposes with 5.111 .152 ha of agricultural land, 4.255 .203 ha is cultivable land or $83,25 \%$. Plough land and vegetable gardens occupy 3.355 .019 ha or $65,64 \%$, and pastures 821.248 ha or $16,07 \%$. Per single inhabitant of our country there is 0,65 ha of agricultural or 0,50 ha of cultivable land/area. Compared to other developed European countries in regard to mentioned fact we are in front of France, Germany, The Netherlands, etc.

1 Review paper supported by the Ministry of Science and Environment Protection, Project no. TR6858 - Revijalni rad je finansiran od strane Ministarstva za nauku i zaštitu životne sredine Projektom broj: TR6858

2 Dr Miroslav Žujović, scientific counselor, Dr Zorica Tomić, scientific counselor, Dr Milan P. Petrović, scientific counselor, grad. eng. Zorica Nešić, research trainee, Institute for Animal Husbandry, Belgrade-Zemun; Dr Snežana Ivanović, research associate, Research Institute of Veterinary medicine of Serbia, Belgrade 
Approximately 1.694 .045 inhabitants live in villages or approx. $27 \%$ of total population. However, in hilly-mountainous region of Serbia there are approx. 638.000 inhabitants or approx. $37,66 \%$ of total population. According to age structure the picture is following: from 19 years of age - 202.448 inhabitants or $11,95 \%$, from 20 to 34 years -144.108 or $8,51 \%$, from 35 to 49 years -263.884 or $15,58 \%$, from 50 to 64 years -471.731 or $27,85 \%$ and over 65 years -312.528 or $18,45 \%$ inhabitants.

Of total population of rural regions $15 \%$ or approx. 1.000 .000 inhabitants - working population - are engaged in agriculture.

Our country has approx. 1.198 .000 village households. Over 700.000 households are engaged in livestock production or $58 \%$. There are 665.903 households or $18,7 \%$ of total number with 1 to 3 ha of agricultural land, 174.359 households or $14,4 \%$ of total number with 5 to 8 ha of agricultural land and 125.697 households with 8 to 10 ha and over 10 ha of agricultural land which is at the level of European Union, 12 countries (average 9 ha). According to Statistical Yearbook 2003 (Statistički godišnjak, 2003) this is not small number of households, approx. 1.250 .000 ha. On total and average area/surface of single household a serious production can be organized whether it is specialized production (livestock, field production, fruit production, etc.) or combined (field and livestock production, livestock and dairy production, livestock and slaughter industry, etc.). It is possible to place on the domestic or foreign market, after satisfying of own needs, surplus of products produced in this region.

Number of goats in Serbia according to survey carried out by the Institute for Animal Husbandry, Belgrade-Zemun in 2003 is approx. 318.000, and according to orientational estimation based on our scientific and breeding experience it should be pointed out that distribution of goats in regions of Serbia is very different. Majority of goats are present in Niš district with 30,56\%, followed by Belgrade district $24,57 \%$, Morava district $17,83 \%$, Podunavlje district 9,55\%, Raška district 9,30\%, Zaječar district 2,62\%, Vojvodina $2,35 \%$ and other districts with approx. $3,22 \%$.

It must be pointed out that our goats, with exception of certain number of goats of Alpine and Saanen breed, are characterized by relatively low milk yield and fertility. It is considered that they produce approx. 300 to 350 litres milk annually Adžić (1981), Adžić et al. (1997), Ćeranić (1984,1987), Žujović (1988, 1993), and if fed adequately (which most often isn't the case) they give 1,5 kids per goat and kidding. This is low production level. Production level of approx. $650-7001$ of milk is achieved through good breeding programme, adequate nutrition and care according to Žujović (1993) and Žujović et al. (2001), and therefore easier to be achieved, whereas for high production level of $800-10001$ and over 10001 it is necessary to apply selection measures which is more difficult and our orientation in the first stage should be approx. 5501 per year.

\section{Size of family household in goat production}

Average cultivable land of family household in Serbia is approx. 3,5 ha and is among the smallest agricultural households in Europe. In majority of industrial countries in Europe average size of household is over 15 ha, Bogavac (1998).

Size of family household as basis for economical production in our conditions wasn't investigated sufficiently. Veselinov et al. (1998) states household of 5 ha as top limit since larger households attract interest of credit institutions. Krstić (1993) defined in his study that goat farm within family household should produce income sufficient to satisfy cost of living of family of four. According to this criterion, farm with 60 to 80 goats with offspring is low limit in conditions of extensive production and with 150 to 200 breeding goats in conditions of intensive production. Similar results were obtained in our research Žujović et al. (2001a).

Next problem that will need to be solved is organization of such production in rural settlements. In many cases, serious limitations facing goat production relate to issue of the size of farm. In order to realize profit from their production farms need to be of specific size and with modern technological solutions. On the other hand, large goat farms or combined sheep and goat farms represent great ecological problem in rural settlements considering that still old technological solutions and traditional breeding methods are applied. One of the possibilities to conciliate these opposites is to transfer/move goat farms outside settlements. In order to achieve economically and biologically more rational size of farm, when certain farmers are not economically strong enough, forming of associations is recommended by two or more producers engaged in same or similar production who would form joint production unit through contract relations. Such solutions 
could also be of interest to dairy plants and other processing firms which could provide raw material with lower cost, necessary quality and adequate dynamics.

If there is expert advisory service operating in certain region which can be very useful and provide considerable expert assistance, different forms of organization of production in goat breeding are more successful.

\section{Role of market in improvement of goat production}

Goat products have been appearing on market in Serbia sporadically for longer period of time, in other words supply of goat products in state of permanent crisis. Number of goats is oscillating, production of milk and meat is in stagnation and consumption is moving to some unofficial commercial channels. Slow changes in breed structure have caused unsatisfactory production results per head of livestock. Consumption of kid and goat meat is low and according to our survey it was approx. 1,5 kg per inhabitant. The same situation is in consumption of milk and dairy products in goat production according to Žujović and Djordjević $(1998,2001)$. More factors with different effect have influenced such situation and its development Žujović et al. $(1992,1992 a, 1999,2001,2004)$. Drastic decrease of demand for such products caused by increase of the price and increase of family income is one of the factors along with sudden interruption of traditional export, sudden increase of production costs, increase of costs of investments (feeds, energy, mechanization, etc.), Žujović and Djordjević (1999). Insecurity of entire processing - marketing sector, bankruptcy of many good managed public farms and forming of many small size private farms and firms with low technological level are also some of the factors, Bogavac and Krstić (1997).

Considering all circumstances it is not probable that consumption of goat products will increase in future. It is more realistic to expect maintaining of previous level of consumption or even its decrease. This is indicated by present developments on domestic market concerning the sale/trade of these products - milk, meat and dairy products in retail sale. In our opinion, possible increase of goat production would only have sense in case of increase of realization on foreign markets and there are already some hints and tendencies in that direction.

Our country wasn't known as exporter of goat products to the world market, meat was sporadically exported to Greece and Italy in previous period. This means that it will be necessary to carry out serious preparations in regard to supply and offer of high quality goat products, such as different types of goat cheeses, kid meat and meat products. Preparations should be initiated in breeding and selection, organization of farmers, education of farmers in order to realize high quantity and quality of production. We assume that if detailed research of foreign markets is carried out and with good marketing strategy there are objective opportunities for us to be present on markets of countries in transition, certain countries of West Europe, America and Middle East. In other words, competition is strong, but export opportunities exist.

\section{Long term objectives of development of goat production}

Strengthening of economical efficiency and change of production structure according to demands of domestic and foreign markets should be basis of goat production along with simultaneous increase of raw material basis and avoiding of import dependency. This field of livestock production should be realized according to world scientific knowledge, technology and standards and actively included in international trade and integration processes. In this sense, ownership and management transformation of households is necessary as well as enabling farms/households through application of modern scientific and technological results and achievements and mutual investments and development of domestic raw material basis to produce high quality products which would be competitive on domestic and foreign market, Krajinović et al. (1995), Krstić (1993, 1995), Žujović (2001a).

Long term objectives of goat breeding should be based on:

- Development of market oriented production - farmers as market producers,

- Production of sufficient quantities of all products for domestic population,

- Supply of all products at price and quality adjusted to purchasing power of population,

- Production for export,

- Application of scientific-technical achievements,

- Preservation of the environment - ecology, application of ISO standards. 
Our long term development strategy and concept should be based on modernization and change of production structure in direction of market orientation and improvement of total efficiency in milk and meat production through organization of:

- Households for production of milk,

- Households for combined production of milk and meat,

- Households for combined market production and processing of milk.

Goat production in Serbia is unorganized, few farms are producing for the market, lack of security in production, production/farms are not inherited by successors who are interested in this production, and many farms become ruined and bankrupt/liquidated. Suggested organization of households for market production eliminates misunderstandings, it places breeders in equal position to workers, there is responsibility for quality and conquer markets, family is financially secure, stable and safe long term production and guarantee that farm will be inherited by son or daughter, etc.

For successful organizing and economical strengthening of farms very important is the choice of the form of business associating in our country, however it is very difficult to recommend the best form. The form of association offering business efficiency, modern technology, rational use of natural resources and equipment (agricultural equipment, machinery, etc.), financial turnover means for crediting current production, supply and placement on the market of products, etc. should have the advantage.

For hilly-mountainous regions of our country where there is still no organized purchasing and processing capacities and which are located on great distance from large city centres, very interesting form of association can be new model of mini diary plant or slaughter house. All kinds of dairy and meat products could be produced in these regions as «organic -high quality biological food» and sold in our trade centres or exported to foreign markets.

Our previous experiences in improvement of goat breeding and results achieved in the world impose the conclusion that for more rapid general improvement of goat breeding a research expert service in charge of realization of breeding programme is of significant importance. For overall programme of development of goat breeding in our country responsible should be following institutions: Republic breeding-selection centres, Institute for Animal Husbandry, Belgrade-Zemun and Novi Sad, national institutes of veterinary medicine and Ministry of Agriculture.

For more rapid and economically more efficient goat production, as well as faster and more efficient organizing of associations of agricultural households/farms it is necessary to solve problems which have had in the past destabilizing effect on goat production:

- Price policy and market,

- Credit policy, and

- Policy of subsidies and incentives.

All developed world countries, especially countries of European Union, have realized that without defined and clear long term policy of prices and market, crediting of production, subsidies and export incentives, there can be no talk of developed livestock production and goat production. Therefore, it is considered that policy of prices and market, price parity, etc. are main conditions for organization of production on farm - production for the market, since goat breeding is serious and long term business demanding at the same time large investments in production buildings, equipment and animals.

Our researches show that until year 2010, because of very low accumulative and reproductive ability of goat production, credit policy should have significant role in providing of financial means for current production and development. Therefore, for long term and stable goat production and stable economical position of farms, three basic credit forms should be:

- Credit for development (buildings, equipment, breeding material, etc.)

- Credit for supply of livestock feed (hay, silage, grain, etc.),

- Credit for current production (financial turnover means).

Credits for development should be approved for the period of at least 10 to 15 years for buildings and 5 to 8 years for equipment and breeding material. Interest rate should be in function of development and follow the accumulation of this branch of agriculture in order to avoid situations when all invested capital is «cancelled» by interest rate or what usually happens that «interest rate eats the production».

If mentioned issues - policy of prices and market and providing of credits, subsidies should not present significant factor. Reason for this is that farmers should be prepared for export and keep in mind that quality of product and delivery date are guarantee for taking place on the European and world market of dairy products, fresh meat and meat products. 


\title{
Conclusion
}

Goat breeding wasn't important for long period of time and it wasn't until the nineties that it gained importance again as branch of livestock production. In other words, goat breeding has proven to be more resistant in times of economical difficulties than other branches of livestock production - pig and poultry breeding, for instance. Necessary support to goat breeding and production present of individual households through adequate economical measures is important because of demographic, economical, regional and even geostrategic reasons.

Perspective of goat production in future should be more significant especially in hilly-mountainous regions, also in certain low land regions where soil quality is good only for pastures and meadows and considering production and labour potentials present on private farms it has certain advantages over other branches of livestock production. However, valorisation of these potentials and advantages is very low and prosperity of goat farms is not possible without transformation of wider economical and social surrounding/environment. The state/government should have decisive role in this process through its institutions but also the market and market mechanisms, business associating of primary producers, processing organizations and commerce, also research and expert service in introduction of new technological solutions, economical policy in transition, etc. Stated recommendations and measures should contribute to faster development in quantity and quality of goat production.

\section{KOZARSKA PROIZVODNJA, POTREBA I MOGUĆNOST U DOMAĆINSTVIMA BRDSKO-PLANINSKIH I RAVNIČARSKIH PODRUČJA}

\author{
M. Žujović, Zorica Tomić, M.P. Petrović, Snežana Ivanović, Zorica Nešić
}

\section{Rezime}

Kozarstvo, jedna od grana stočarstva danas je na najnižem proizvodnom i ekonomskom nivou u našoj zemlji za poslednjih 40 godina, pa je neophodno shvatiti i ukazati na značaj kozarstva za privredni razvoj zemlje, standard ljudi, uposlenost stanovništva koji živi na selu, a oko 25 - 30\% od ukupnog broja je direktno ili indirektno vezano za selo.Zato je neophodno izraditi dugoročan program razvoja kozarstva koji treba da ima snagu obaveze i odgovornosti za njegovu realizaciju. Sve ostalo za posledicu imaće dalje još veće zaostajanje ove grane stočarstva i kašnjenje za razvijenim svetom.

Cilj ovog rada je da dâ opšti pregled uslova, trenutnog stanja i problema u kozarskoj proizvodnji i predloži rešenja i da preporuke za ovu proizvodnju u narednih deset godina. Poseban naglasak je stavljen na individualna gazdinstva koja će se baviti kozarstvom kao primarnom proizvodnjom na brdskoplaninskom i ravničarskom području.

Značaj kozarstva u dužem vremenu kontinuirano je opadao, da bih 90-tih godina ova grana stočarstva ponovo dobila na važnosti. Dakle, u vremenima ekonomskih teškoća, kozarstvo je znatno otpornije od nekih drugih grana stočarstva - svinjarstva, živinarstva. Nužnu podršku kozarskoj proizvodnji na individualnim gazdinstvima odredjenim privrednim merama potrebno je dati iz niza razloga kao što su: demografski, ekonomski, regionalni, pa i geostrateški.

Perspektiva kozarstva u narednom periodu trebalo bi da bude još značajnija u brdsko-planinskim, a i u odredjenim ravničarskim regionima, gde je bonitet zemljišta odgovarajući samo za pašnjake i livade, s obzirom na proizvodne i radne potencijale u privatnom vlasništvu, takođe ima i neke komparativne prednosti u odnosu na neke druge grane stočarstva. Medjutim, valorizacija tih potencijala i prednosti je veoma niska, a prosperitet kozarskih gazdinstava nije moguć bez transformacije šireg privrednog i društvenog okruženja. Značajnu ulogu u tom procesu trebalo bi da ima država, preko svojih institucija, ali i tržište i njegovi mehanizmi, poslovno povezivanje primarne proizvodnje, preradjivačkih organizacija i trgovine, nauke $i$ struke sa novim tehnološkim rešenjima, ekonomska politika u tranziciji i dr. Napred navedei predlozi i mere trebalo bi da doprinesu bržem razvoju brojnog i kvalitativnog povećanja u kozarskoj proizvodnji.

Ključne reči: Koza, gazdinstvo, odgoj, proizvodnja, mleko, meso, jarad. 


\section{Literatura}

1. ADŽIĆ N., LJUMOVIĆ M. (1981). Morphological and productional characteristics of autochtonic goat from the rocky soil in Montenegro, 32 FEZ, pp. 258-262. Zagreb.

2. ADŽIĆ N., ŽUJOVIĆ M., SAVIĆ MILICA, MARKOVIĆ BOŽIDARKA, MARKOVIĆ M., BAUMAN FRIDA (1997). Genetski resursi u kozarstvu u Jugoslaviji. Savremena poljoprivreda, Vol. 46. pp 245250, Novi Sad.

3. BOGAVAC VIOLETA, KRSTIĆ B. (1997): Veličina poljoprivrednog gazdinstva i proces tranzicije. „Agrarni i ruralni razvoj u sistemskim refoemama“ Tematski Zbornik, Institut za ekonomiku poljoprivrede, str. 43-45. Beograd.

4. BOGAVAC VIOLETA (1998); Sistemi ovčarske proizvodnje u Srbiji. Institut za istraživanja u poljoprivredi Srbija. str. 5-152. Beograd.

5. ĆERANIĆ VUKOSAVA (1984): Kozarstvo. Biblioteka unosnih zanimanja. str. 5-140. Beograd.

6. ĆERANIĆ VUKOSAVA (1987): Značaj proizvodnje kozijeg mleka. IX Savetovanje. „Ovčije i kozije mleko" str. 15-25. Vlašić.

7. VESELINOV D. I SAR. (1988): Projekat unapredjenja proizvodnje i životnih uslova na selu Agrobanka. str. 3- 50. Agrobanka. Beograd.

8. KRAJINOVIĆ M., ČOBIĆ T., ŽUJOVIĆ M., MEKIĆ C., GRUBIĆ G. (1995): stanje i pravci razvoja ovčarstva i kozarstva. IV Kongres o hrani „Stočarska proizvodnja, prerada, kvalitet, promet, ekonomija i zaštita životne sredine“. Zbornik referata, II sekcija, knjiga 3 , str. 18-25. Beograd.

9. KRSTIĆ B.(1993): Ekonomski aspekti i mere za unapredjenje ovčarske i kozarske proizvodnje. Zbornik radova:"Pravci razvoja ovčarstva i kozarstva u SR Jugoslaviji“". str.25-30. Novi Pazar.

10. KRSTIĆ I SAR.(1995): Modeli zemljoradničkih gazdinstava usmerenih na stočarsku proizvodnju. Aleksandrija str. 28-36. Beograd.

11. STATISTIČKI GODIŠNJK SRBIJE (2003): RS Republički Zavod za statistiku, 3-425.

12. ŽUJOVIĆ M. (1988): Oplemenjivanje populacije koza gajenih na farmi „Bačevsko polje“ u Dimitrovgradu. Magistarski rad. Poljoprivredni fakultet, Zemun. str. 5-174. Beograd - Zemun.

13. ŽUJOVIĆ M., NENADIĆ M. (1992): Stanje i mogućnosti razvoja ovčarstva i kozarstva. Jugoslovensko savetovanje:"Unapredjenje govedarstva, ovčarstva i kozarstva u cilju veće proizvodnje mleka“. Zbornik radova str. 23-26. Niška banja.

14. ŽUJOVIĆ M., NENADIĆ M., ŽUJOVIĆ MIROSLAVA (1992 a): Genetsko stanje i unapredjenje koza u cilju povećanja proizvodje mleka. Jugoslovensko savetovanje „Unapredjenje govedarstva, ovčarstva i kozarstva u cilju veće proizvodje mleka“. Zbornik radova. str. 47-49. Niška banja.

15. ŽUJOVIĆ M.(1993): Proizvodnja i osobine mleka domaće bele koze. Doktorska disertacija. Poljoprivredni fakultet, Novi Sad. str 3-150. Novi Sad.

16. ŽUJOVIĆ M., DJORDJEVIĆ-MILOŠEVIĆ SUZANA (1998): Sheep and goat native milk products as a basis for the sustainable agricultural production in the ESAs. 6th International symposium on the milking of small ruminante. Hellenic Society of Animal Production. pp.288-292. Athenes.

17. ŽUJOVIĆ M., DJORDJEVIĆ-MILOŠEVIĆ SUZANA (1999): Sheep production models for woodlands of the Panonija Lowland in Yugoslavia. Grassland and Woodly Plants in Europe. vol. 4. pp. 429433. Grassland Science in Europe.

18. ŽUJOVIĆ M. PETROVIĆ P.M., KRAJINOVIĆ M., GLUHOVIĆ M., MEKIĆ C. (1999a): Genetski resursi i unapredjenje u kozarskoj proizvodnji. Savremena poljoprivreda. vol. 48., 1-2. str. 43-47. Novi Sad.

19. ŽUJOVIĆ M. (2001a): Ovčarstvo i kozarstvo u našim domaćinstvima za naredni vek. Savetovanje „Nauka, praksa i promet u agraru“. Agroinovacije. str. 21-25. Vrnjačka Banja.

20. ŽUJOVIĆ M., PETROVIĆ P.M., DJORDJEVIĆ-MILOŠEVIĆ SUZANA, GLUHOVIĆ M., STRSOGLAVEC STELA (2001): Perspektiva ovčarskih i kozarskih domaćinstava u novom milenijumu. Savremena poljoprivreda. vol. 50. 3-4. str. 337-341. Novi Sad.

21. ŽUJOVIĆ M., TOMIĆ ZORICA, JOSIPOVIĆ S., NEŠIĆ ZORICA, ĆINKULOV MIRJANA, PIHLER I. (2004): Stanje i mogućnosti kozarske proizvodnje. Acta agriculturae Serbica. Proceeding of 10th National Symposium on Forage Crops. vol. IX. 17. pp. 33-41. Čačak. 